June - 2009

\title{
Transparency in Cooperative Online Education
}

\author{
Christian Dalsgaard \\ Aarhus University, Denmark \\ Morten Flate Paulsen \\ The Norwegian School of Information Technology, Norway
}

\begin{abstract}
The purpose of this article is to discuss the following question: What is the potential of social networking within cooperative online education? Social networking does not necessarily involve communication, dialogue, or collaboration. Instead, the authors argue that transparency is a unique feature of social networking services. Transparency gives students insight into each other's actions. Cooperative learning seeks to develop virtual learning environments that allow students to have optimal individual freedom within online learning communities. This article demonstrates how cooperative learning can be supported by transparency. To illustrate this with current examples, the article presents NKI Distance Education's surveys and experiences with cooperative learning. The article discusses by which means social networking and transparency may be utilized within cooperative online education. In conclusion, the article argues that the pedagogical potential of social networking lies within transparency and the ability to create awareness among students.
\end{abstract}

Keywords: Online education; social networking; transparency; e-learning; cooperative learning; learning community

\section{Introduction}

The purpose of this article is to discuss the following question: What is the pedagogical potential of social networking to support cooperative online learning? Often, the potential of social software and Web 2.0 is related to collaborative activities and user-generated content, not least in the context of online education. In other words, "social" is often described as communication, construction, and collaboration. This article will focus on other qualities of social software and Web 2.0 that are characteristic of social networking and are found in services such as weblogs, social networking sites, micro-blogging, and social presence tools. The article will argue that a central characteristic of social networking is the potential to facilitate transparency between students. The basic assumption is that transparency is important to cooperative online education. 
People can cooperate only if they know about each other and have access to some common information and services.

We understand transparency as students' and teachers' insight into each other's activities and resources. Transparency means that you and your doings are visible to fellow students and teachers within a learning environment. For instance, transparency could mean that students and teachers are made aware of and have access to each other's interests, thoughts, concerns, ideas, writings, references, and assignments. The purpose of transparency is to enable students and teachers to see and follow the work of fellow students and teachers within a learning environment and in that sense to make participants available to each other as resources for their learning activities.

Transparency is not a given, especially within online education. Students might work at a distance and individually, and, thus, they are not necessarily aware of the activities of other students. In their individual work, however, students write notes, search for literature, find relevant websites, write assignments, etc. This information and these products are relevant to other students. A central aspect of cooperative learning is to enable students to make use of each other while at the same time maintaining individual freedom. This article illustrates the theory of cooperative freedom with current examples from NKI Distance Education in Norway. With an enrollment of about 14,000 students, the institution is one of the European megaproviders of online education (Paulsen, 2007) and is Scandinavia's largest provider of distance education. About 75 percent of the students are enrolled in NKI's more than 450 online courses, and to accommodate this volume NKI operates a self-developed learning management system (LMS) called SESAM. The system was developed to support NKI's model for large-scale distance education, which features individual student progress as it is described in the articles NKI Fjernundervisning: Two Decades of Online Sustainability (Paulsen \& Rekkedal, as cited in Paulsen, 2003) and Cooperative Online Education (Paulsen, 2008). The authors of the current article refer to three internal evaluation reports regarding individual progress planning, follow-up, and cooperation. The first survey (Paulsen, 2005) was answered by 364 students, the second (Paulsen, 2006) by 542 students, and the third (Paulsen, 2008) by 763 students.

\section{Social Networking and Cooperative Learning}

Social networking technologies have actualized the question concerning which social infrastructures support learning. There is an ongoing debate about the potential of different forms of social interaction, i.e., groups, communities, collectives, connections, and networks (Dron \& Anderson, 2007; Downes, 2007; Wenger et al., 2005; Anderson, 2008; Ryberg \& Larsen, 2008; Jones, 2004; Jones et al., 2006; Siemens, 2005). The debate has its origin in the concept of network, which challenges a number of other forms of social relations. As Dron and Anderson (2007) state, research and practice in the area of e-learning has focused primarily on groups. They describe groups as "individuals who see themselves as part of that group." A group, such as a study group, is a defined collection of individuals who in some way are engaged in joint work. 
Further, Jones et al. (2006) criticize Wenger's concept of communities of practice and the tradition of computer supported collaborative learning (CSCL). Jones et al. argue that the two traditions are not able to describe the kinds of relations that exist within learning environments. The traditions of communities of practice and CSCL have focused on participation, collaboration, and negotiation of meaning (Wenger 1998), or, in other words, on tight-knit structures. The use of technology in support of groups and communities of practice has often focused on collaboration, especially within the field of CSCL (Jones et al., 2006). This highlights the emphasis within elearning and also more broadly within technology-supported learning on supporting or developing tight-knit social structures.

The concept of network has challenged the concept of a tight-knit social construct. Networks are loosely organized structures (Dron \& Anderson 2007) in which people do not necessarily collaborate or communicate directly. However, the question is what role networks play in relation to learning. A conclusion of this debate is that there exists a form of social interaction - social networking - that learning theories have difficulty explaining. More questions arise: What kind of relations support learning, and, specifically, how do networks support learning?

Jones (2004) uses the concept of networked learning and draws a direct line between networking and learning. He stresses the importance of facilitating "connections between learners, learners and tutors, and between learners and the resources they make use of in their learning" (Jones et al. 2006, p. 90). Jones (2004) writes, "Networked learning doesn't privilege any particular types of relationships between people or between people and resources." The problem with this definition is that it does not establish which kinds of relations should be supported. Studies within networked learning have, according to Jones (2004), focused primarily on strong links, and he prefers to draw attention to the so-called weak ties. This is an interesting focus because it is the support of weak ties that makes social networking unique. Thus, we will focus on what could be termed weak ties. However, as Ryberg and Larsen (2008) argue, it is important to clarify what defines weak ties and how they differ from strong ties.

Social networking relates to concepts within social capital theory. Central to social capital theory is the point that human relations are an important and valuable resource (Field, 2003). Social capital theory describes characteristics of different types of social structures and relations, which makes it a relevant theory in an elaborated discussion of social networking and transparency (Coleman, 1990). However, our argument for the potential of transparency within social networks is based on learning theory, i.e., the theory of cooperative freedom and socio-cultural theory. Although relevant, we believe a coupling of these different theoretical approaches is outside the scope of this article. For our purpose, it is necessary to clarify how different kinds of social relations support learning. Thus, it is necessary to make a connection between learning and types of social relations.

The theory of cooperative freedom can offer such a connection. The first version of the theory was published in the monograph From Bulletin Boards to Electronic Universities (Paulsen, 1992). It was updated in the book Online Education and Learning Management Systems (Paulsen, 2003), and further versions with more examples are available in English (Paulsen, 2006 and 
2008), Portuguese (2007), and Norwegian (Paulsen, 2007). The theory is based on three theoretical perspectives on distance education, described by Keegan (1996, p. 56). The three perspectives are autonomy and independence (e.g., Moore, 1988), industrialization (e.g., Peters, 1988), and interaction and communication (e.g., Holmberg, 1988).

Learning theories can be individual, collaborative, or cooperative, and online education technology can support the theories. In a white paper from Epic Group p.l.c. on personalization and e-learning (Clark, 2004, p. 26), the author concludes that technology may support both individual learning and access to social networks. In the article Collaborative versus Cooperative Learning, Panitz (2003) points out that there is a certain amount of overlap or inter-concept usage between cooperative and collaborative learning and that it is an elusive goal to find a distinction between their definitions. There is considerable ambiguity about the meaning of collaborative learning. The two terms (cooperative learning and collaborative learning) are, therefore, typically used as interchangeable and synonymous (Johnson et al., 2004, p. 788). Our distinction between the two concepts is in line with the use of the terms within the fields of computer supported collaborative learning (CSCL) and computer supported cooperative work (CSCW) (Roschelle \& Teasley, 1995; Dillenbourg et al., 1996). Roschelle and Teasley (1995) offer the following insight:

We make a distinction between 'collaborative' versus 'cooperative' problem solving. Cooperative work is accomplished by the division of labour among participants, as an activity where each person is responsible for a portion of the problem solving. We focus on collaboration as the mutual engagement of participants in a coordinated effort to solve the problem together. (Roschelle \& Teasley, 1995, p. 70)

In the theory of cooperative freedom, the three terms are clearly distinguished and related to the distinction above. They are described as follows:

Individual learning provides superior individual flexibility but very limited affinity to a learning community. It has a strong position in online education delivered by institutions with a tradition in distance education. Individual learning environments can be more or less rigid or flexible, for example, with regard to time, place, and pace.

Collaborative learning requires participation in a learning community but limits individual flexibility. One may say that collaborative learning requires that students sink or swim together. Collaborative learning is common in online education offered by traditional face-to-face institutions.

Cooperative learning focuses on opportunities to encourage both individual flexibility and affinity to a learning community. Cooperative learning seeks to foster some benefits from individual freedom and other benefits from cooperation 
in online learning communities. It thrives in virtual learning environments that emphasize individual freedom within online learning communities.

Another way to distinguish between the three terms is to claim that individual learning is conducted alone, collaborative learning depends on groups, and cooperative learning takes place in networks. One may also add that the ties between people are much tighter in groups than in networks. The differences between the three learning theories are illustrated in Figure 1.

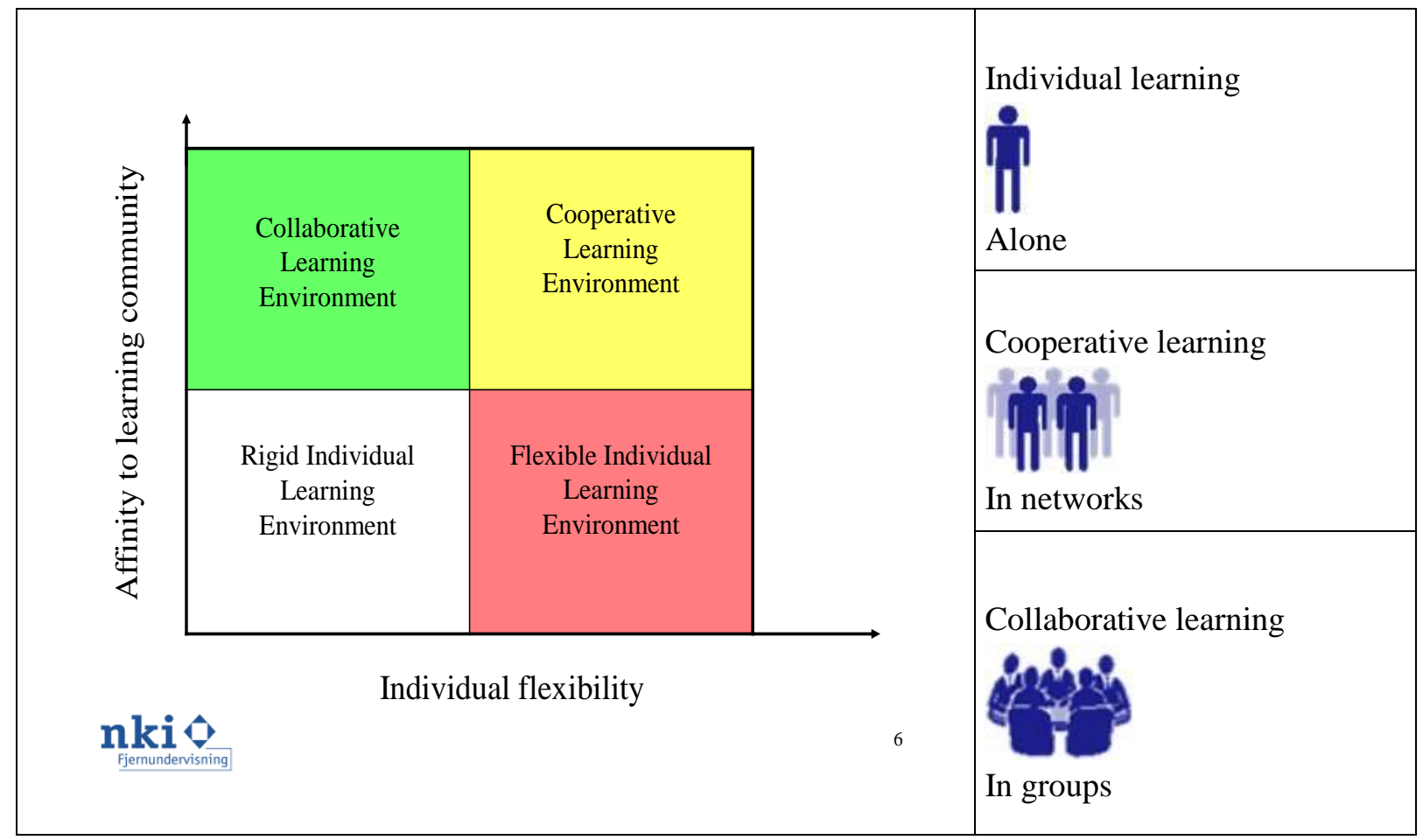

Figure 1. Individual, cooperative, and collaborative learning environments.

Well-designed virtual cooperative learning environments build on a number of means that support individual flexibility and other means that facilitate affinity to a learning community. The theory of cooperative freedom is based on the following three pillars:

1. voluntary but attractive participation,

2. means promoting individual flexibility, and

3. means promoting affinity to learning community.

The theory of cooperative freedom is supported by a socio-cultural perspective, which emphasizes problem-oriented and self-governed learning activities (Dalsgaard, 2006). Learning is first of all considered an active process. Learning takes place through problem-oriented activities, in which students are directed at solving a problem or achieving a goal. In this respect, the sociocultural approach emphasizes the importance of the activities of the individual. However, the approach also stresses that individual activities are always situated in a collective practice 
(Vygotsky, 1978; Brown, Collins, \& Duguid, 1989; Bang \& Dalsgaard, 2006; Leont'ev, 1978; Engeström, 1987).

Consequently, social relations are central to learning in a socio-cultural approach. However, collective activity does not take place only within collaborative and tight-knit groups or communities. Relations between activities may not promote awareness of the activities of other people. Thus, an important objective within a learning environment is to support consciousness and awareness of the activities of others. This is a main objective of cooperative learning.

From the perspective of the theory of cooperative freedom and the socio-cultural approach, an individual's awareness of the activities of other individuals becomes a focal point of attention within learning. The objective is not community-building or collaboration but increased awareness. Supporting awareness within a cooperative learning environment will be the focus of the discussion of the pedagogical potential of social networks.

\section{Transparency and Cooperative Learning}

\section{Transparency as a Special Kind of Communication}

As stated above, social networking does not necessarily involve dialogue or collaboration. Instead, we will argue that transparency is a dominant feature of social networking. An interesting aspect of social networking is that the starting point is the individual or personal. This is in opposition to discussion forums in which communication always takes place in a shared forum. In a social networking site each individual has a personal page and profile, which the individual develops and modifies. Other people can view these pages and follow activities of their "friends." In other words, actions within a social networking site are transparent. This creates a kind of indirect or passive form of communication and sharing. In opposition to discussion forums, people do not necessarily send messages or documents in order to communicate or share. Instead, they update their profile, add pictures or texts, etc. to their own page. The starting point for this kind of communication is students' own work and their personal pages. The personal page is then shared in a social network. The personal page provides opportunities for personalization; the individual can choose the look and content of the page. An important function of the personal page is that it serves as the individual's personal representation on the web. This makes social networking sites radically different from discussion groups and other community-based tools. In a discussion forum you are represented by your posts only, whereas you are always "present" in a social network through your personal page.

The personal page also provides a basis for social networking. In discussion forums, on the other hand, the shared forum itself is the starting point. The social space for interaction is developed beforehand, whereas the social network for interaction develops on the basis of the personal page. Socialization begins when a personal page is connected to other personal pages of other individuals. Each individual builds a network of personal relations. In that respect networks are also personal. A unique form of communication in social networks takes place through subscriptions and notifications. This kind of communication means that people within a network subscribe to personal pages (such as weblogs) and are notified whenever a page is modified or 
whenever a person performs any kind of action within the network. Consequently, a form of indirect communication emerges, indirect in the sense that it is not intentional.

Based on this we argue that communication within social networks, to a large extent, is a matter of awareness and transparency. Our objective is not to reject relations that exist within groups or communities. Instead, we wish to highlight the pedagogical potential of social networking in relation to transparency. Transparency is particularly relevant within cooperative learning, where students are working on related projects or assignments but are not collaborating. Within cooperative online learning a central challenge is to enable students to follow the work of their colleagues. If students are unaware of the activities of fellow students, they might not make use of each other. This problem is reinforced within online education, where students do not meet faceto-face (Paulsen, 2008).

\section{Cooperative Learning Requires Transparency}

Cooperative learning and a socio-cultural approach provide a strong motive for support of transparency between students. A cornerstone in cooperative online education is that cooperation should be voluntary, but attractive and appealing. It should be offered as an appealing opportunity to those who seek cooperation. The challenge is therefore primarily to help those who are interested in cooperation to engage in a network of suitable learning partners. In addition it is necessary to stimulate the rest of the students to contribute to the learning community. This means that students should not be encouraged or tempted to withdraw from the learning community. Total seclusion is undesirable. Students should be stimulated to be visible as potential partners and resources for others. Transparent information could be a huge cooperative resource. The dilemma is that students who do not contribute to the community cannot be perceived as learning resources for others. The potential of the learning community will then be diluted. So one may argue that a successful cooperative learning community may depend on a mutual understanding that the members have a commitment to serve as a resource for the learning community.

NKI Distance Education has developed the following philosophy on cooperative online learning: NKI Distance Education facilitates individual freedom within a learning community in which online students serve as mutual resources without being dependent on each other.

Version 6 of SESAM, NKI's learning management system, was developed in 2007 when there was considerable focus on Web 2.0 services. Therefore, it was based on a systems development philosophy stating that the services should be personal, interactive, dynamic, and transparent. Further, the services should stimulate students and teachers to produce, share, and refine content they will all benefit from.

Transparency is important for cooperative online education. People can only cooperate if they know about each other and have access to some common information and services. Cooperation will benefit when general and personal information related to the learning and the learners is available directly or indirectly to the learning community. This transparent information may 
include personal information about the users and statistics related to the users' deployment of the online tools. It may further include work students and teachers provide in online notebooks, blogs, and discussion forums as well as results from quizzes, surveys, and assignments.

Transparency implies that users to a certain extent can see and be seen, but it is important to find a suitable transparency level. Transparency is also an important driver for improved quality. It has the following three positive effects on quality:

\section{Preventive quality improvement}

We are prone to provide better quality when we know that others have access to the information and contributions we provide.

\section{Constructive quality improvement}

We may learn from others when we have access to their data and contributions.

\section{Reactive quality improvement}

We may receive feedback from others when they have access to our data and contributions.

Transparency may reduce the number of low quality contributions and may make high quality work more accessible as paragons for others. In transparent online learning environments, poor contributions from teachers and course designers cannot be hidden easily behind closed doors. It is important to realize that transparency must be handled carefully with regard to privacy issues. The users must be confident that their privacy is assured. They should be able to choose their preferred privacy level and understand how this choice controls how much of their personal data and contributions will be available to others. The challenge of finding the correct transparency level is illustrated in Figure 2.

\section{Transparency barometer}

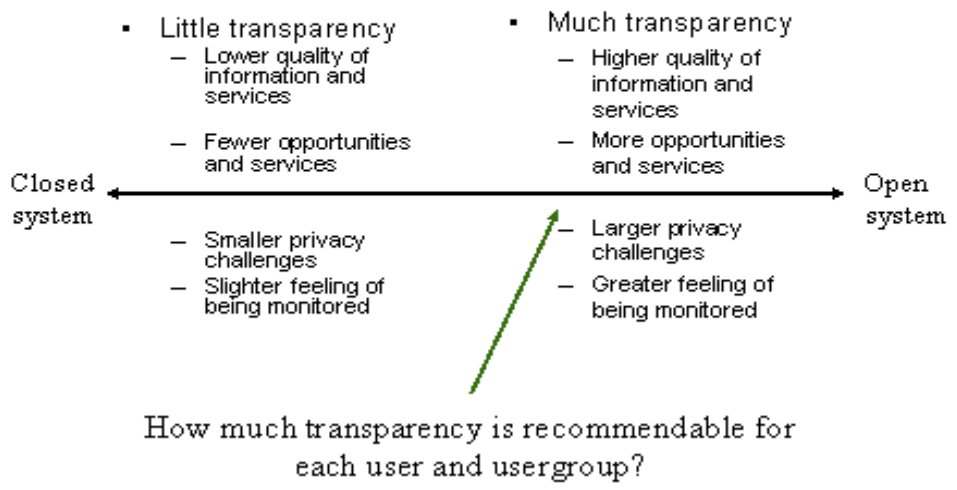

Figure 2. Transparency and privacy. 
A few examples of information that may be more or less transparent in virtual learning environments are presented in Table 1. It is an interesting exercise to discuss the consequences of making each of the items in the matrix transparent to various user groups.

Table 1

Transparency Matrix for Discussion of Transparency Levels in Virtual Learning Environments

$\begin{array}{lllll}\text { Some information that may be transparent } & \text { Self? } & \text { Teachers? } & \begin{array}{l}\text { Students } \\ \text { in class? }\end{array} & \begin{array}{l}\text { Students } \\ \text { in other classes? }\end{array} \\ \text { The teachers average response times } & \text { Yes } & \text { Yes } & \text { No } & \text { No } \\ \text { Information about students' progress plans } & \text { Yes } & \text { Yes } & \text { Yes } & \text { No } \\ \text { The last time teacher logged on } & \text { Yes } & \text { Yes } & \text { Yes } & \text { No } \\ \text { Students grades } & \text { Yes } & \text { No } & \text { No } & \text { No } \\ \text { Student assessment of teacher performance } & \text { Yes } & \text { No } & \text { No } & \text { No } \\ \text { Teachers' feedback on student assignments } & \text { Yes } & \text { Yes } & \text { No } & \text { No } \\ \text { Teachers' contributions in their online forums } & \text { Yes } & \text { Yes } & \text { Yes } & \text { No } \\ \text { Teachers' personal presentations } & \text { Yes } & \text { Yes } & \text { Yes } & \text { Yes } \\ \text { The courses each teacher teaches } & \text { Yes } & \text { Yes } & \text { Yes } & \text { Yes } \\ \text { How many students each teacher serves } & \text { Yes } & \text { Yes } & \text { Yes } & \text { Yes }\end{array}$

Note: The matrix is filled in for an imaginary learning environment.

Information that is too personal to be transparent could still be very useful if it is presented as statistics or averages. Individual grades are usually only presented to the student and to the teacher. However, it might be useful to make average course grades transparent to everyone.

\section{Transparency and Social Presence Tools}

The Internet trends that are most interesting for online education today are related to social software and Web 2.0. Some well-known examples of social software that are relevant for online education are blogs, wikis, social networking sites, RSS, and social bookmarking. The most interesting characteristic of Web 2.0 is the development of social networks that are hugely successful since the users produce, share, and refine information of mutual interest and benefit for all community members. Social networking sites (such as MySpace, Facebook, Bebo, and Ning) are websites used to build online networks. However, the principles of social networking are not confined to social networking sites. For example, media sharing sites such as flickr and Youtube also contain elements of social networking. The difference is that media sharing sites revolve around media materials, whereas the starting point for social networking sites is socializing. Further, social networking can be accomplished by relations between blogs or by the use of social awareness services such as Twitter or Friendfeed. In relation to the distinction between different social networks, Engeström (2005) has initiated a discussion of what makes social networks successful. He argues that "The social networking services that really work are the ones that are built around objects." This is a relevant point to bear in mind in relation to transparency. 
Developing what Engeström calls "objects of sociality" supports transparency because objectcentered social networks are based on the availability and visibility of objects.

\section{Transparency as a Means to Promote Affinity to Learning Communities}

There are a number of means that could be used to strengthen affinity to virtual learning communities. Transparency and social presence services are central to these means. It is paramount that the participants are visible and accessible. In addition, the community members must be urged and stimulated to contribute to the community and to benefit from it. In the following sections, some of these means are discussed.

\section{Cooperative student catalogues.}

Student catalogues are important tools for showing students that they have access to a learning community. A comprehensive catalogue that provides relevant information about students is crucial to students acquiring an overview of the learning community. Student catalogues usually provide information about all students enrolled in a course; however, if students can access information about the students enrolled in other courses offered by the institution, they may benefit from taking part in a larger learning community. Moreover, a catalog that includes alumni could be of interest to students who seek advice on courses they are considering or on future employment.

To facilitate cooperation, a student catalogue should include information that makes it easy to initiate and maintain communication, such as e-mail addresses, telephone numbers, chatting identities, etc. It may also include information on geographical location (e.g., zip codes) to facilitate identification of potential partners for occasional face-to-face meetings. Similarly, it may include progress plan information so that students can identify peers who are working with the same study unit. Finally, one may argue that student catalogues should include CV-type information to make it possible to search for peers who have special competencies.

Student catalogues must address privacy issues appropriately. Some information in student catalogues may be regarded as sensitive and may require student consent. Some students may also be opposed to inclusion in a student catalogue. The challenge is to find the balance between

providing as much relevant information as possible to stimulate cooperation without trespassing students' privacy thresholds. A viable solution is to ask students for permission to make the information available to the staff, to the students enrolled in the actual course, or to all students in all courses.

\section{Cooperative learner profiles.}

The acronym CLIP, which refers to the phrase cooperative learner information profile, has evolved as a result of one of the author's deliberations (Paulsen, 2006) on effective cooperative student catalogues. Using CLIPs, LMSs may help students find motivated and suitable learning partners (study buddies). CLIPs could herald a new and innovative pedagogy for cooperative 
learning. They could provide efficient tools for establishing smaller and larger networks with the right mix of students, and they could facilitate contact between junior students and experienced students who are willing to function as personal mentors. Further, they could facilitate small colloquial networks of students who live in the same geographic area or who have similar progress plans. These networks may result in reduced dropout rates and better learning.

Based on CLIPs and algorithms for teaming students, the system should suggest partners that make cooperation interesting. Elements from NKI's implementation of CLIPs are illustrated in Figure 3 and Figure 4. The students should be provided with enough information to establish contact and with appropriate tools to maintain cooperation. However, developing suitable algorithms is not a trivial task.

\section{I would like to have a learning partner}

I accept that my data is available to my learning partners

\section{G Global Everyone on the Internet may see my presentation \\ C Open All NKI students may see my presentation \\ Limited The students in my course may see my presentation \\ Closed Only my teachers and the NKI staff may see my presentation}

Figure 3. Choose learning partner preference and visibility level: An element from the students' user interface.

By the end of January 2009, NKI's 9,628 users had indicated their visibility and learning partner preferences, as shown in Table 2.

Table 2

Distribution of Visibility and Learning Partner Preferences

\begin{tabular}{|l|l|l|l|l|}
\hline & $\begin{array}{l}\text { Want learning } \\
\text { partners }\end{array}$ & $\begin{array}{l}\text { Don't want } \\
\text { learning partners }\end{array}$ & Sum & Percent \\
\hline Closed & 137 & 875 & 1012 & $10.51 \%$ \\
\hline Limited & 2260 & 2980 & 5240 & $54.42 \%$ \\
\hline Open & 763 & 1709 & 2472 & $25.68 \%$ \\
\hline Global & 537 & 367 & 904 & $9.39 \%$ \\
\hline Sum & 3697 & 5931 & 9628 & $100.00 \%$ \\
\hline Percent & $38.40 \%$ & $61.60 \%$ & $100.00 \%$ & \\
\hline
\end{tabular}




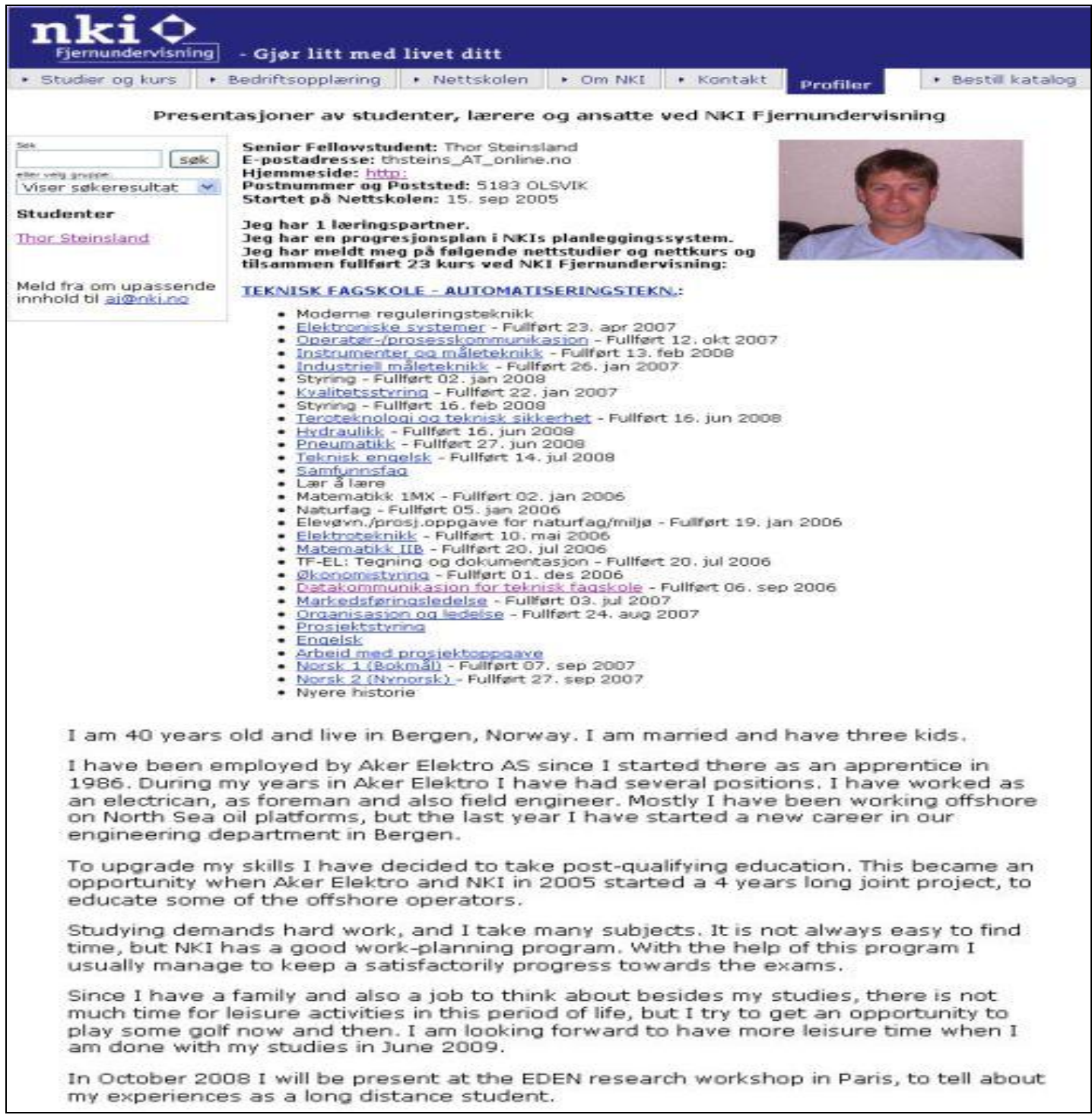

Figure 4. A personal presentation of an NKI student. Included with permission from Thor Steinsland.

CLIPs may build on theories, ideas, and features discussed in social capital and social software literature. Resnick (2002, p. 1) argues that socio technical capital is a new construct that provides a framework for generating and evaluating technology-mediated social relations. In online education one may think of this as learning capital. In a blog entry, Butterfield (2003) characterizes social software as tools that people use to interact with other people, employing information about identity, presence, relationships, conversations, and groups.

Although Facebook, one of the most successful social software services, was developed as a network service for students, social software applied for organized educational purposes is scarce. In Norway, the university of Troms $\varnothing$ has introduced a social software service (www.hvaskjer.no) to enroll more students from secondary schools. The Norwegian School of Management has introduced an online alumni service, and in its alumni magazine, the school (2005, p. 92) states 
that 9,000 alumni have made use of it. All alumni have online contact cards that they may update and supplement with information about their work and professional interests, and alumni may search the complete database of information in order to find useful resources and contacts.

An online survey (Paulsen, 2005) completed by 154 NKI students showed that the majority wanted closer cooperation with one or more students. As many as 64 percent stated that they probably or definitely wanted closer cooperation. Only 16 percent responded that they probably or definitely did not want closer cooperation. The verbal comments also showed that many respondents wanted cooperation. Many stated that they needed, wanted, or missed cooperation and study buddies. Some pointed out that it was difficult to contact other students; others wanted better tools to find partners. However, there were some respondents who stated that they didn't need cooperation. Further, they thought cooperation should be voluntary and they stated that they preferred to study without being dependant on others. The survey also showed that 71 percent of the respondents were positive or very positive to see each other's progress plans. Similarly, 76 percent were positive or very positive about obtaining access to each other's zip codes.

In a large institution, teachers could also benefit from finding partners for cooperation. Therefore, NKI provides teachers with a discussion forum and dynamic contact information for all 150 online teachers and the online courses they teach.

\section{Learning partners.}

Based on the learning profile concept and the student survey referred to in this article (Paulsen 2005), in March 2006, NKI introduced a service to help students find learning partners (Slåtto \& Paulsen, 2006). The students who seek learning partners are asked to do the following:

1. Register their personal presentations.

2. Decide who may access their presentations.

3. Search for potential learning partners.

4. Invite somebody to become their learning partner.

By November 2006, 3,100 students had registered a personal presentation (an increasing number of the presentations include a personal picture). At the same time, 2,500 had indicated their privacy level and preference regarding having learning partners. About 450 of the students had found one or more learning partners.

As of December 2007, 3,900 students had registered a personal presentation. At the same time, 3,700 had indicated their privacy level and preference regarding having learning partners, as indicated in Table 3. About 750 of the students had found one or more learning partners. 
Table 3

Student Preferences regarding Learning Partners and Privacy

\begin{tabular}{|l|l|l|l|l|}
\hline & $\begin{array}{l}\text { Want learning } \\
\text { partners }\end{array}$ & $\begin{array}{l}\text { Do not want } \\
\text { learning } \\
\text { partners }\end{array}$ & Sum & Percent \\
\hline Closed & 79 & 657 & 736 & $20.0 \%$ \\
\hline Limited & 1192 & 706 & 1898 & $51.5 \%$ \\
\hline Open & 752 & 303 & 1055 & $28.6 \%$ \\
\hline Sum & 2023 & 1666 & 3689 & \\
\hline Percent & $54.8 \%$ & $45.2 \%$ & & \\
\hline
\end{tabular}

The first major survey (Paulsen, 2008), including a question about the learning partner services, had responses from 763 NKI students. The results showed that $54 \%$ of the respondents were very satisfied or satisfied, and $2 \%$ were dissatisfied or very dissatisfied. The remaining respondents were either neutral or expressed no opinion. The report concludes that the service has the potential to be developed further and that the students need more time to become familiar with the services.

\section{Cooperative assignments.}

Assignments are a crucial way to support learning theories. An assignment should consist of a task and a direction. An assignment focusing on one task can easily support individual, cooperative, or collaborative learning by varying the assignment directions. This is illustrated in the following example:

Assignment task

Explain the differences between individual learning, cooperative learning, and collaborative learning.

Alternative assignment directions

\section{Individual learning direction}

Send your submission as an e-mail to your teacher.

\section{Cooperative learning direction}

Discuss the assignment with a colleague or a peer student in your network. Write a short summary of the discussion and send it as an e-mail to your teacher.

\section{Collaborative learning direction}

Write a paper in a group with one or two other students and submit the paper as an e-mail to your teacher. 


\section{Cooperative assessment.}

Online assessment may be grouped in four categories (Paulsen, 2003, page 68): self-assessment, computer assessment, tutor assessment, and peer assessment. All categories could have a cooperative flavor if they are designed with transparency and cooperation in mind:

1. Computer-based assessment could be cooperative if students exchange or have access to statistics, results, or information derived from all or some other students taking the tests.

2. Self-assessment could be cooperative if students are encouraged to exchange selfassessments or if students may access some statistics or information from other students who have completed self-assessments.

3. Peer assessment could be cooperative if students are encouraged to assess each other's work voluntarily.

4. Teacher assessment could be cooperative if the students have access to some of the information the tutor provides or derives from assessing other students.

Portfolio assessment can support cooperative learning if the system allows students to access and comment on each other's portfolios.

\section{Cooperative gating (COG).}

Wells (1992) described gating as a pacing technique that denies students access to information before they have completed all prerequisite assignments. The acronym COG, which refers to cooperative gating, has evolved as an NKI term. It signals that students must complete a task to get access to a cooperative resource. This could for example be used as a stimulus for motivating students to answer in-text questions. They are allowed to see what others have answered only if they provide an answer others may read.

\section{Cooperative evaluation and quality barometers.}

Evaluation and quality control are crucial but challenging in large-scale online education that is based on individual progress plans. Some of the challenges are related to the following questions:

- When should it be done: once a year, near the end of the course, or continuously?

- What should be evaluated if the aim is to improve quality?

- How should the results be presented, and how transparent should they be to have the best impact?

- How could evaluation be automated and managed as part of a reasonable workload?

In cooperative learning environments, the findings and results should be reasonably transparent, and relevant information should be available to the appropriate user groups so that they can learn from the results and understand that they are members of a larger learning community. 
NKI developed an evaluation tool which was used for the first time in 2003. The system allows NKI to develop common forms of questionnaires and evaluation forms. Each form can be assigned to one or more user categories, e.g., teachers, students in one course, or all students. A user may respond only once and all replies are anonymous. When a user responds, the evaluation database is updated and the user is granted access to a personal evaluation report. The transparent reports that are generated from the database vary according to the user category:

- Students may see a report showing qualitative statistics of interest to students in their course.

- Teachers may see the same report as the students with additional teacher information. The teacher information could come from certain parts of the questionnaire or from data related to other courses (for the purpose of comparison).

- Administrative staff may see comparative reports showing responses from all user groups and questionnaires. This means, for example, that one can compare responses in all courses in the LMS system. This could be used to identify teachers who receive excellent evaluations or courses that receive worrying evaluations.

One weakness is that the system is not meant for continuous evaluation. Therefore, NKI is integrating a new feature, termed quality barometer, which continuously records evaluation data and presents dynamic reports on important indicators of quality.

The evaluation tool was used in a survey among all NKI online students at the end of 2007. There were 763 students who answered the questionnaire, which included nine quantitative and 10 qualitative questions. Students who were enrolled in more than one course could respond one time per course. There were close to 900 responses. The results are available in an internal NKI report (Paulsen, 2008), and the main conclusion states that NKI can be very satisfied with the results. The responses provide substantial information about how the students perceive the tools NKI has developed to support cooperative learning. An overview of the responses to the nine quantitative questions is provided in Table 4. 
Table 4

Summary of the Responses to the Nine Quantitative Questions in the 2007 Survey

\begin{tabular}{|c|c|c|c|c|c|c|c|}
\hline \multirow[b]{2}{*}{$\begin{array}{l}\text { How satisfied are you with the } \\
\text { following: }\end{array}$} & \multicolumn{6}{|c|}{ Percentages } & \multirow{2}{*}{ 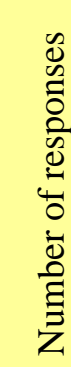 } \\
\hline & 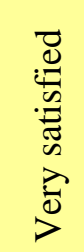 & 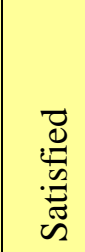 & 蔦 & 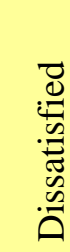 & 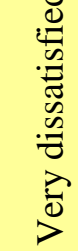 & 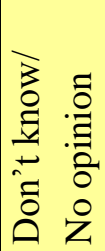 & \\
\hline NKI's submission system? & 55.7 & 34.1 & 6.2 & 0.8 & 0.2 & 2.9 & 885 \\
\hline NKI's planning system? & 47.7 & 38.7 & 10.1 & 2.3 & 0.2 & 1.0 & 894 \\
\hline Being an online NKI student? & 37.2 & 49.4 & 8.2 & 3.5 & 0.8 & 0.9 & 898 \\
\hline This course? & 30.2 & 54.1 & 10.8 & 2.7 & 0.6 & 1.7 & 892 \\
\hline The teacher's work? & 36.4 & 36.7 & 12.8 & 4.7 & 1.2 & 8.2 & 891 \\
\hline NKI's follow-up system? & 26.0 & 44.9 & 19.0 & 2.7 & 0.8 & 6.6 & 890 \\
\hline The course material? & 23.0 & 59.0 & 11.0 & 4.9 & 1.5 & 0.6 & 896 \\
\hline The contact with NKI? & 22.9 & 45.5 & 21.5 & 5.3 & 1.0 & 3.8 & 892 \\
\hline The learning partner system? & 16.6 & 36.5 & 30.4 & 1.1 & 0.8 & 14.6 & 892 \\
\hline
\end{tabular}

\section{Personal tools.}

Personal tools are tools that first and foremost support the activities of the individual. This means that personal tools are used by the individual for individual purposes. In that sense, they are related to a personal profile or web page within a social network, which is developed and used by the individual. For example, personal tools could support activities such as finding literature, writing texts, taking notes, keeping track of links, solving assignments, etc.

Personal tools support transparency when they are made available to others. The personal tools become social. It is possible to use the personal tools as the starting point for social networks. Students can connect to and subscribe to the personal tools of other students. The web service del.icio.us is a good example of a personal tool that can be used socially. Del.icio.us is a social bookmarking service, which enables people to collect their bookmarks on a web page. Initially the service supports individual organization and use of bookmarks. However, the bookmarks are made available for everyone on the web, which means that they are shared. Students can use similar personal tools to organize their work, collect literature, write notes, brainstorm, develop thoughts and ideas, write assignments, etc. Sharing these tools with other students through networking supports transparency and consequently awareness among students. 


\section{Transparency: Potential for Online Education}

What is the pedagogical potential of social networking? We have discussed the pedagogical potential of social networking for cooperative learning. We have argued that transparency is important to online education. In relation to cooperative learning with continuous enrollment and examinations, a challenge is to motivate students to engage in joint work. We have argued that transparency is a prerequisite for distance students to work cooperatively. Transparency enables students to be visible to each other as potential partners and resources.

Following the outlined theory of cooperative freedom and the socio-cultural approach, an important objective is to support an individual's consciousness and awareness of the activities of others. This can be achieved by making a variety of information transparent, for instance by developing student catalogues and learner profiles, by encouraging learners to become partners, and by sharing personal learning tools.

The result is a different kind of transparency than is found in, for instance, discussion forums. Whereas discussion forums and other tools for direct communication and collaboration focus on direct sharing, social networking can support students' indirect sharing of resources, thoughts, ideas, productions, writings, notes, etc. This kind of sharing can provide students with insights into the workings of other students, and, thus, give them an increased consciousness and awareness of the activities of other students.

The pedagogical potential lies within developing social networks in which students' activities are visible to other students. The potential is to support transparency through a combination of personalization and socialization and through sharing personal information and tools within social networks (Dalsgaard 2006).

\section{Conclusion}

Social networking sites are not the new learning management systems. From the perspective of the theory of cooperative freedom, however, the special kind of communication and interaction afforded by social networking sites is interesting and has pedagogical potential. From this point of view, social networking should be considered as a supplement to other tools. The potential of social networking lies within transparency and the ability to create awareness among students. 


\section{References}

Anderson, T. (2008) Networks vs. groups in higher education. Message posted to http://terrya.edublogs.org/2008/03/17/networks-versus-groups-in-highereducation/\#more-90

Bang, J., \& Dalsgaard, C. (2006). Rethinking e-learning: Shifting the focus to learning activities. In E. K. Sorensen \& D. Murchú (Eds.), Enhancing learning through technology. Information Science Publishing.

BI, (2005). BI Alumni - din arena for nettverksbygging. In BI Magasinet, June 2005.

Brown, J. S., Collins, A., \& Duguid, P. (1989). Situated cognition and the culture of learning. Educational Researcher, 18(1), 32-42.

Butterfield, S. (2003). Blog entry retrieved July 14, 2005, from www.sylloge.com/personal/2003_03_01_s.html\#91273866

Clark, D. (2004). Personalisation and e-learning. Brighton, UK: Epic Group p.l.c.

Coleman, J. S. (1990). Foundations of social theory. Cambridge, Massachusetts and London: The Belknap Press of Harvard University Press.

Collis, B., \& Moonen, J. (2001). Flexible learning in a digital world. London: Kogan Page.

Dalsgaard, C. (2006). Social software: E-learning beyond learning management systems. European Journal of Open, Distance and E-Learning, 2006/II. http://www.eurodl.org/materials/contrib/2006/Christian_Dalsgaard.htm

Dillenbourg, P., Baker, M., Blaye, A., \& O’Malley, C. (1996). The evolution of research on collaborative learning. In E. Spada \& P. Reiman, (Eds.), Learning in Humans and Machine: Towards an interdisciplinary learning science ( pp. 189-211). Oxford: Elsevier. Retrieved March 18, 2009, from http://tecfa.unige.ch/tecfa/publicat/dil-papers2/Dil.7.1.10.pdf

Downes, S. (2007). Learning networks in practice. Emerging Technologies for Learning, 2, 19-

27. British Educational Communications and Technology Agency. http://ijklo.org/Volume3/IJKLOv3p029-044Downes.pdf

Dron, J., \& Anderson, T. (2007). Collectives, networks and groups in social software for elearning. Proceedings of World Conference on E-Learning in Corporate, Government, Healthcare, Higher Education, Quebec. www.editlib.org/index.cfm/files/paper 26726.pdf.

Engeström, J. (2005). Why some social network services work and others don't - Or: the case 
for object-centered sociality. Message posted to http://www.zengestrom.com/blog/2005/04/why some social.html

Fagerberg, T. (2005). Fjernstudenters vurdering av nettbaserte pedagogiske tjenester. Unpublished master's thesis. København: Danmarks Pædagogiske Universitet.

Field, J. (2003). Social capital: Key ideas. Routledge: New York.

Holmberg, B. (1988). Guided didactic conversation in distance education. In D. Sewart, D.

Keegan, and B. Holmberg (Eds.), Distance education: International perspectives (pp. 114-22). London/New York: Croom Helm/St. Martins Press.

Johnson, D. W., \& Johnson, R. T. (2004). Cooperation and the use of technology. In D. Jonassen (Ed.), AECT handbook. Retrieved July 15, 2008, from http://lrnlab.edfac.usyd.edu.au/CoursesPG/Resources/AECT/chp30.pdf

Jones, C., Ferreday, D., \& Hodgson, V. (2006). Networked learning a relational approach - weak and strong ties. Proceedings of the Networked Learning Conference 2006.

Jones, C. (2004). The conditions of learning in networks. Kaleidoscope CSCL SIG. Lausanne.

Keegan, D. (1996). Foundations of distance education (3rd ed.). London: Routledge.

Leont'ev, A. N. (1978). Activity, consciousness, and personality. http://www.marxists.org/archive/leontev/works/1978/index.htm.

Moore, M. G. (1983). On a theory of independent study. In D. Sewart, D. Keegan, and B.

Holmberg (Eds.), Distance education: International perspectives (pp. 68-94). London/New York: Croom Helm/St. Martin's Press.

Panitz, T. (2003): Collaborative versus cooperative learning - a comparison of the two concepts which will help us understand the underlying nature of the interactive learning. Retrieved July 15, 2005, from http://home.capecod.net/ tpanitz/tedsarticles/coopdefinition.htm

Paulsen, M. F et al. (2008). Resultater fra spфrreunders $\phi$ kelsen blant nettstudentene ved NKI Fjernundervisning høsten 2007. Internal report. Oslo: NKI.

Paulsen, M. F. (2008). Cooperative online education. Seminar.net 4(2). Retrieved November 18, 2008, from www.seminar.net/current-issue/cooperative-online-education

Paulsen, M. F. (2007). Cogs, clips e outros instrumentos de apoio à aprendizagem cooperativa 
realizada em ambientes virtuais. In B. Almeida et al. (Eds), Livro de actas encontro de educacao em fisca do ensino basico ao supirior no sec, XXI.

Paulsen, M. F. (2007). Kooperativ frihet som ledestjerne i nettbasert utdanning. Bekkestua: NKI Forlaget.

Paulsen, M. F. (Ed) (2007). Megaproviders of e-learning in Europe. Bekkestua: NKI Forlaget.

Paulsen, M. F. (2006). Cogs, clips and other instruments to support cooperative learning in virtual learning environments. In U. Bernath \& A. Sangrà (Eds.), Research on competence development in online distance education and e-learning - Selected papers from the 4th EDEN research workshop, Castelldefels/Spain.

Paulsen, M. F. (2006). Resultater fra spфrreunders $\phi$ kelsen blant nettstudentene ved NKI Fjernundervisning høsten 2005. Internal report. Oslo: NKI.

Paulsen, M. F. (2005). Resultater fra spфrreunders $\phi$ kelsen om NKI Fjernundervisnings planleggings- og oppfølgingssystem. Internal report. Oslo: NKI.

Paulsen, M. F. (2003). Online education and learning management systems: Global e-learning in a Scandinavian perspective. Oslo: NKI Forlaget. Retrieved July 18, 2005, from www.studymentor.com/

Paulsen, M. F., \& T. Rekkedal, (2003). NKI Fjernundervisning: Two decades of online sustainability. In M. F. Paulsen, Online education and learning management systems: Global e-learning in a Scandinavian perspective. Oslo: NKI Forlaget. Retrieved July 18, 2005, from www.studymentor.com/studymentor/NKI.pdf

Paulsen, M. F. (1992). From bulletin boards to electronic universities: Distance education, computer-mediated communication, and online education. University Park, Pennsylvania: The American Center for the Study of Distance Education.

Peters, O. (1988). Distance teaching and industrial production: A comparative interpretation in outline. In D. Sewart, D. Keegan, \& B. Holmberg (Eds). Distance education: International perspectives (pp. 95-111). London/New York: Croom Helm/St. Martin's Press.

Resnick, P. (2002). Beyond bowling together: Socio technical capital. In J. Carroll (Ed.), Human computer interaction in the new millennium. (pp. 247-272). Addison-Wesley. Retrieved July 18, 2005, from www.si.umich.edu/\%7Epresnick/papers/stk/ResnickSTK.pdf.

Roschelle, J., \& Teasley, S. D. (1995). The construction of shared knowledge in collaborative problem solving. In C. O’Malley (Ed.), Computer supported collaborative learning (pp. 69-97). Springer-Verlag. 
Ryberg, T., \& Larsen, M. C. (2008). Networked identities: Understanding relationships between strong and weak ties in networked environments. Journal of Computer Assisted Learning, 24, 103-115.

Siemens, G. (2005). Connectivism: A learning theory for the digital age. http://www.elearnspace.org/Articles/connectivism.htm.

Slåtto, T., and M. F. Paulsen, (2006). Learning partner - opportunities for cooperation in distance learning. Retrieved November 14, 2006, from www.elearningeuropa.info/index.php?page $=$ doc\&doc $\_i d=8294 \&$ doclng $=6 \&$ menuzone $=2$

Vygotsky, L. S. (1978). Mind in society. Harvard University Press.

Wells, R. (1992). Computer-mediated communication for distance education: An international review of design, teaching, and institutional issues. University Park, Pennsylvania: The American Center for the Study of Distance Education.

Wenger, E. (1998). Communities of practice. Cambridge University Press.

Wenger, E., White, N., Smith, J. D., \& Rowe, K.(2005). Technology for communities. http://www.ewenger.com/pub/index.htm.

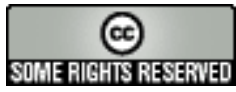

